\title{
Steeping of Whole Dried Maize Seeds in Buffers Altered Fatty Acid Ionization State, Composition, and Lipase Activity
}

\author{
Raphael Lartey Abban, Justice Kwabena Sarfo \\ Department of Biochemistry, University of Cape Coast, Cape Coast, Ghana \\ Email: ssarfo@ucc.edu.gh
}

How to cite this paper: Abban, R.L. and Sarfo, J.K. (2017) Steeping of Whole Dried Maize Seeds in Buffers Altered Fatty Acid Ionization State, Composition, and Lipase Activity. Food and Nutrition Sciences, 8, 989-1000.

https://doi.org/10.4236/fns.2017.811071

Received: September 3, 2017

Accepted: November 12, 2017

Published: November 15, 2017

Copyright $\odot 2017$ by authors and Scientific Research Publishing Inc. This work is licensed under the Creative Commons Attribution International License (CC BY 4.0).

http://creativecommons.org/licenses/by/4.0/

\begin{abstract}
Steeping is a simple model of studying the activation and modulation of the physiological pathways involved in seed germination. In this study, steeping of grains of the 'obatanpa' maize variety in buffers at different $\mathrm{pH}$ was monitored through the measurements of lipase activity, oil yield, fatty acid component and unsaturation, and germination capacity. Lipase activity of grains steeped for four days decreased in the order: $\mathrm{pH} 3>\mathrm{pH} 5>\mathrm{pH} 7>\mathrm{pH} 9>\mathrm{pH}$ 11. Decreasing lipase activity was corroborated with decreasing free fatty acid components, protein concentrations and oil yields. The unsaturation components of the oil fractions only marginally increased with increasing steeping media $\mathrm{pH}$. Three major components were detected by TLC in all oil fractions. The unique components were confirmed by their uniform UV-absorption spectra converging at an isosbestic point of $290 \mathrm{~nm}$. Germination capacity was much reduced for seeds steeped in buffered media for 24 hours compared with seeds steeped in portable water though the pattern of germination, which was monitored for five days, did not change. This study has demonstrated the use of $\mathrm{pH}$ changes of steeping medium to modulate physicochemical properties and germination of seeds. The physicochemical changes were observed after seeds have been submerged under steeping buffer for four days. Practical application: With proliferation of specialty maize hybrids, the study provides an insight into the development of experimental protocols for the selection of types of maize grain for preparation of foods and beverages in terms of general characterization and lipolytic activity, which have implications for flavor, taste and odor of the final products. The imminence of this in some traditional ways of preparing malted and fermented maize foods and beverages, which go through days of steeping, cannot be overemphasized. This study therefore provides another dimension to the manipulation of the steeping stage to develop varieties of maize-based product.
\end{abstract}




\section{Keywords}

Lipase Activity, 'Obatanpa' Maize Variety, Oil Fraction, Steeping Media pH

\section{Introduction}

Malting of cereal grains is a well-studied process applied in industries and in many traditional fermented food and beverage preparations. The three major steps involved in malting; steeping, germination and kilning are used in that order to obtain products as packages of starch, sugars, proteins, amino acids, enzymes, fatty acids, vitamins, minerals and other minor constituents [1]. Among these steps, steeping; a natural means of breaking seed dormancy, provides the most convenient, effective and yet simple laboratory approach of investigating physiological and environmental effectors of seed germination [2]. Steeping softens the cell wall as the seed imbibe water and thereby activating hydrolytic and reductive enzymes for the release of nutrients; amino acids, sugars, fatty acids and others from food reserves. Diastatic power of rice malts was increased when gibberellic acid; a plant hormone with increased activity on germinating seeds, was included in the steeping water [3]. Steeping also removes pigments, pesticides, bitter substances and microorganisms from grains [4]. The above events are important determinants of the quality of malt and fermented cereal-based products processed through steeping [5]. Activity of lipase is the one major source of off-flavors and odors during the preparation of malted and fermented food products. Polyunsaturated free fatty acids released from the hydrolysis of triglyceride by lipase and their oxidative and carbonyl-amine derivatives are the major source of off-flavours, odours, and bitter taste, which can taint food products [6]. Phosphatidyl ethanolamine and phosphatidyal choline sphingomyelin fractions are the main sources of the disagreeable fishy odours in many food systems [7]. Short-chain fatty acids such as butyric acid and caproic acids possess soapy flavors can also taint food products [8]. On the contrary, lipases are used as flavor enhancers in certain types of food processing [9]. Lipase is also required for the degradation of lipid vesicles, which encapsulate starch granules to maximize amylase release of simple sugars; the primary goal in any malting process [10]. Thus, over-expression or under-expression of lipase during steeping may affect the quality of malted and fermented products. Since expression of enzymes in the cell could be regulated by the levels of products of enzyme catalysis, the free fatty acids present in the seed could alter the expression of lipase [11], we hypothesized that this transcriptional alteration could equally be induced by the overall changes in $\mathrm{pH}$ balance in the storage bodies including the oil bodies. The presence of alkaline and acidic lipases with reciprocal expression pattern in germinating castor seeds as reported by Huang et al., 1978 [12], may lend credence to this hypothesis. We therefore tested the hypothesis by steeping seeds of 'Obatanpa' an open-pollinated quality protein maize (QPM) variety 
[13], in aqueous medium buffered at different $\mathrm{pH}$ and determined the changes in lipase induction and the residual oil fractions in grain homogenates.

\section{Materials and Method}

\subsection{Source of Maize Grains}

The 'Obatanpa' maize grains were obtained from one of the Ministry of Food and Agriculture designated shops, which sells seeds to Ghanaian farmers for cultivation of farmlands. Seeds were disinfected by submerging in sufficient quantity of a $1 \%$ sodium hypochlorite solution, thereafter washed several minutes under potable running water and finally with distilled water. The disinfected seeds were used immediately in the experiment after a brief air-drying without prior storage.

\subsection{Steeping and Extraction of Oil from Maize Grains}

50-gram maize grains were each submerged for four days in a 50-mL medium of $0.1 \mathrm{M}$ universal buffer (citric acid $6.843 \mathrm{~g}$, potassium phosphate monobasic 4.080 g, sodium tetra-borate $8.421 \mathrm{~g}$, tris $\{$ hydroxymethyl $\}$ aminomethane $3.633 \mathrm{~g}$ and potassium chloride $2.238 \mathrm{~g}$ ) at $\mathrm{pH} 3.0,5.0,7.0,9.0$, and 11.0 respectively. Steeped grains were briefly air-dried and ground into fine, semi-dried particles, loaded into a conical flask containing $100 \mathrm{~mL}$ hexane and fitted with a reflux condenser. Extraction by refluxing was always performed at $66^{\circ} \mathrm{C}$ for four hours. The hexane extracts were filtered and completely evaporated to oils.

\subsection{Determination of Oil Yield}

Oily fractions were poured into separate pre-weighed evaporating dishes representing the $\mathrm{pH} 3.0,5.0,7.0,9.0$, and 11.0. The filtrates were dried on a boiling water bath for 10 minutes to remove residual hexane. At room temperature, the dishes and their oil contents were re-weighed and the percentage of oil present in each 50-gram weight of maize grains was calculated.

\subsection{Physicochemical Analysis of Oil}

$20 \mu \mathrm{L}$ aliquot of each oil sample representing the $\mathrm{pH} 3.0,5.0,7.0,9.0$ and 11.0 was spotted onto TLC plates (silica gel 60 F254 Sigma-Aldrich, UK) and resolved in hexane:ethanol:acetic acid solvent system at ratio 80:18:2. TLC spots were detected first in UV-illumination box and lastly in an iodine chamber. The retardation factor for each spot was calculated as the ratio of the distance each spot travelled on the TLC plate over the distance travelled by the front of the solvent system. $0.2 \mathrm{~g}$ of each oil sample in ethanol was also scanned with a spectrophotometer (Shimadzu UV mini 1240, Japan) between $250 \mathrm{~nm}$ and $300 \mathrm{~nm}$ at interval of $10 \mathrm{~nm}$ to determine the absorption spectrum of each sample. Same amount of oil was used according to AOAC [14] methods but at different proportions of reagents to determine iodine number and free fatty acid values of each oil sample by the formulas below: 


$$
\text { Iodine number }=\frac{12.69 \times(V 2 \times V 1) \times N t}{W} ; \text { Acid value }=\frac{56 \times N s \times V}{W}
$$

$V 1=$ volume of thiosulphate used in test sample; $V 2=$ volume of thiosulphate used in blank

$N t=$ normality of thiosulphate solution; $N s=$ normality of sodium hydroxide solution

$V=$ volume of sodium hydroxide used; $W=$ weight of oil sample.

\subsection{Preparation of Crude Lipase Homogenates}

200 grams each of the 'Obatanpa' maize grains was steeped for four days in 200 $\mathrm{mL}$ of universal buffer of $\mathrm{pH} 3.0,5.0,7.0,9.0$ and 11.0 respectively. The softened seeds of each sample were homogenized in $50 \%$ cold acetone after a brief drying period. The homogenates were centrifuged at $15,000 \mathrm{~g}$ for 10 minutes at $4^{\circ} \mathrm{C}$. The protein precipitates were filtered and washed with excess acetone and the resultant precipitates reconstituted in $0.1 \mathrm{M}$ sodium phosphate buffer $(\mathrm{pH} 7)$ and kept at $-20^{\circ} \mathrm{C}$ to serve as the crude lipase. The above experiment was repeated three times and lipase activity was calculated for each run for the different steeping $\mathrm{pH}$.

\subsection{Total Protein}

The protein concentration $(\mathrm{mg} / \mathrm{ml})$ of the crude lipase preparation was determined using the biuret method [15]. Standard albumin preparations were used to construct protein calibration curve.

\subsection{Determination of Crude Lipase Activity}

Maliks et al., 2000 [16] method of lipase determination was employed with few changes. Olive oil emulsion was prepared by adding $25 \mathrm{~mL}$ olive oil to $150 \mathrm{~mL}$ of triton-X100 followed by vigorous vortexing. $5 \mathrm{~mL}$ of the emulsified olive oil was treated with $20 \mathrm{~mL}$ of the crude lipase preparation containing 0.42 grams equivalent of crude protein. Reaction mixture was incubated at $37^{\circ} \mathrm{C}$ for 5 minutes. The reaction was stopped after adding $10 \mathrm{~mL}$ of a $96 \%$ ethanol. Controls were produced by the same reaction but ethanol was present in the reaction mixture during the 5-minute incubation period. The reaction mixtures were titrated against $2 \mathrm{mM}$ sodium hydroxide using phenolphthalein as indicator and the amount of released free fatty acid was calculated for each sample. One unit of lipase activity is defined as the $\mu \mathrm{mol}$ of free fatty acid released after one minute of crude lipase incubation with emulsified olive oil.

\subsection{Measurements of Changes in Seed Germination}

250 grains of 'obatanpa' maize were disinfected in $200 \mathrm{~mL}$ of $1 \%$ sodium hypochlorite solution. Grains were briefly air-dried and steeped for 24 hours in 0.1 $\mathrm{M}$ universal buffer. 250 steeped grains were prepared for buffer at different $\mathrm{pH}$; 3.0, 5.0, 7.0, 9.0 and 11.0. Each 250-grain sample was divided into five 50-grain 
samples representing $1^{\text {st }}, 2^{\text {nd }}, 3^{\text {rd }}, 4^{\text {th }}$, and $5^{\text {th }}$ day of germination. These were spread on separate petri dishes overlaid with cotton soaked in their respective buffers. Samples were wrapped in clean aluminum foil and kept in a dark cupboard. Germination was observed for five days and the percentage daily germination was calculated for each sample $(\mathrm{pH})$ on each day during the five-day test period. Daily numbers of germinated seeds were used to measure the germination process by the methods I to $\mathrm{V}$ below:

1) Germination Percent (GP, \%) at end of the five-day test period [17].

2) Germination Energy (GE, \%) [18].

3) Emergence Energy Value (EEV, \%) [19].

4) Germination Value (GVc, \%) [20].

5) Germination Value (GVdp, \%) [21].

Each germination experiment was repeated twice and the average value was calculated for each of the methods I to $\mathrm{V}$ and recorded accordingly.

\subsection{Statistical Analysis}

Analyses were conducted for replicate samples. Measurements were recorded and standard deviations were calculated from Microsoft Excel (2007 edition) spreadsheet.

\section{Results}

\subsection{Steeping pH Affected Seed Oil Content and Composition}

Universal buffer contains organic and inorganic ions compatible with many life forms markedly altered the oil metabolism of the 'obatanpa' maize seeds during steeping. Figure 1 shows that the $\mathrm{pH}$ of the steeping buffer altered the content of oil in seeds of the 'obatanpa' maize during the four-day steeping. Percentage oil yield was higher at lower $\mathrm{pH}$ 3.0, 5.0 and 7.0 than at higher $\mathrm{pH} 9.0$ and pH11.0. Equal amounts of oil extracted from maize samples steeped at different $\mathrm{pH}$ each gave same three major components $\mathrm{A}, \mathrm{B}$ and $\mathrm{C}$ on TLC irrespective of the steeping $\mathrm{pH}$ as shown in Figure 2.

Again, equal amounts of the oil samples were scanned in a spectrophotometer (Shimadzu, UV-mini, Japan), at varying wavelengths. In Figure 3, the spectra patterns support the existence of similar chemical entities in all samples but whose proportions were affected during the period of steeping.

In Figure 3, the spectra pattern and the maximum absorption of oil samples in the range of $260 \mathrm{~nm}$ to $270 \mathrm{~nm}$ with isosbestic point at $290 \mathrm{~nm}$ attest to the similarity of the major oil components $(\mathrm{A}, \mathrm{B}, \mathrm{C})$ in oil fractions obtained at the different steeping $\mathrm{pH}$. However, there was higher absorptivity associated with oils obtained at $\mathrm{pH} 9.0$ and $\mathrm{pH} 11.0$ compared to oils at $\mathrm{pH} 5.0$ and $\mathrm{pH} 7.0$ as shown in Figure 2. This difference could be due to changes in the concentration of any of the major components A, B and C; an unsaturated component will have higher UV absorptivity than a saturated component.

Changes in oil yield observed from $\mathrm{pH}$ 3.0, 5.0, 7.0, 9.0, to 11.0 of the steeping medium were supported by decreasing free fatty acid content from $32.41 \pm 5.3$, 


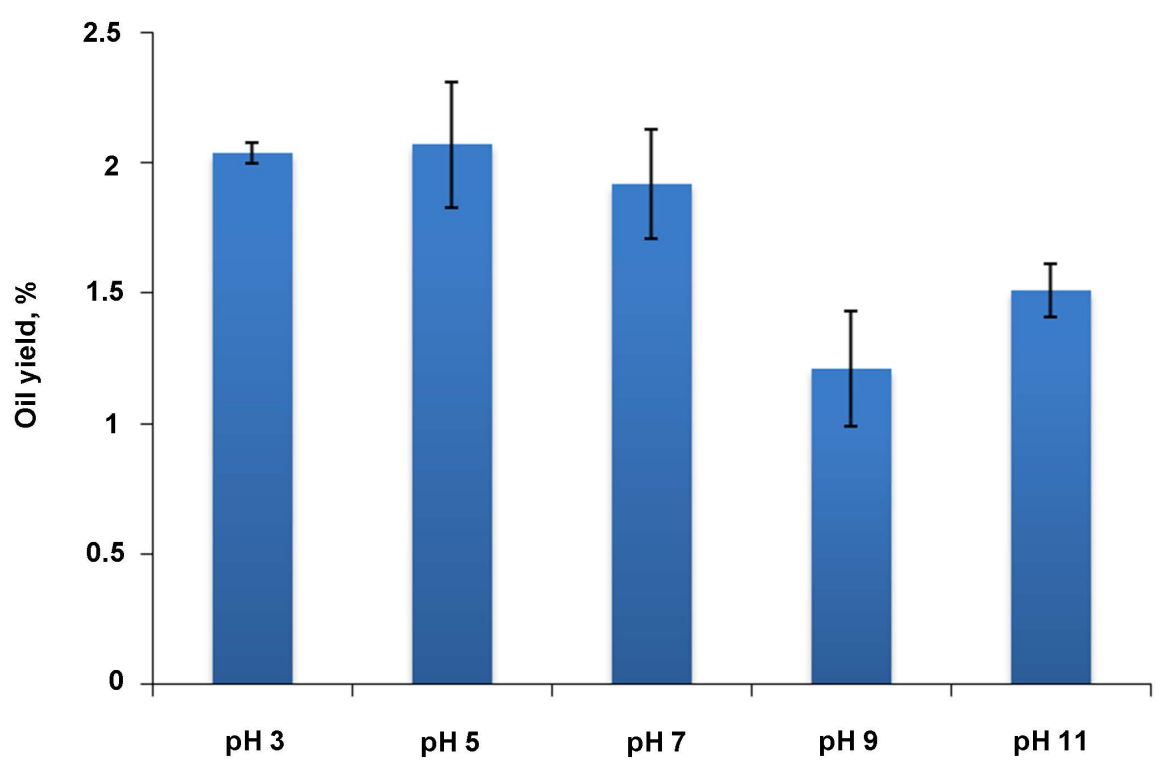

Figure 1. The yield (\%) of oil extracted from maized steeped at different buffer $\mathrm{pH}$. Equal amount of maize grains steeped at different $\mathrm{pH}$ gave different oil fractions.

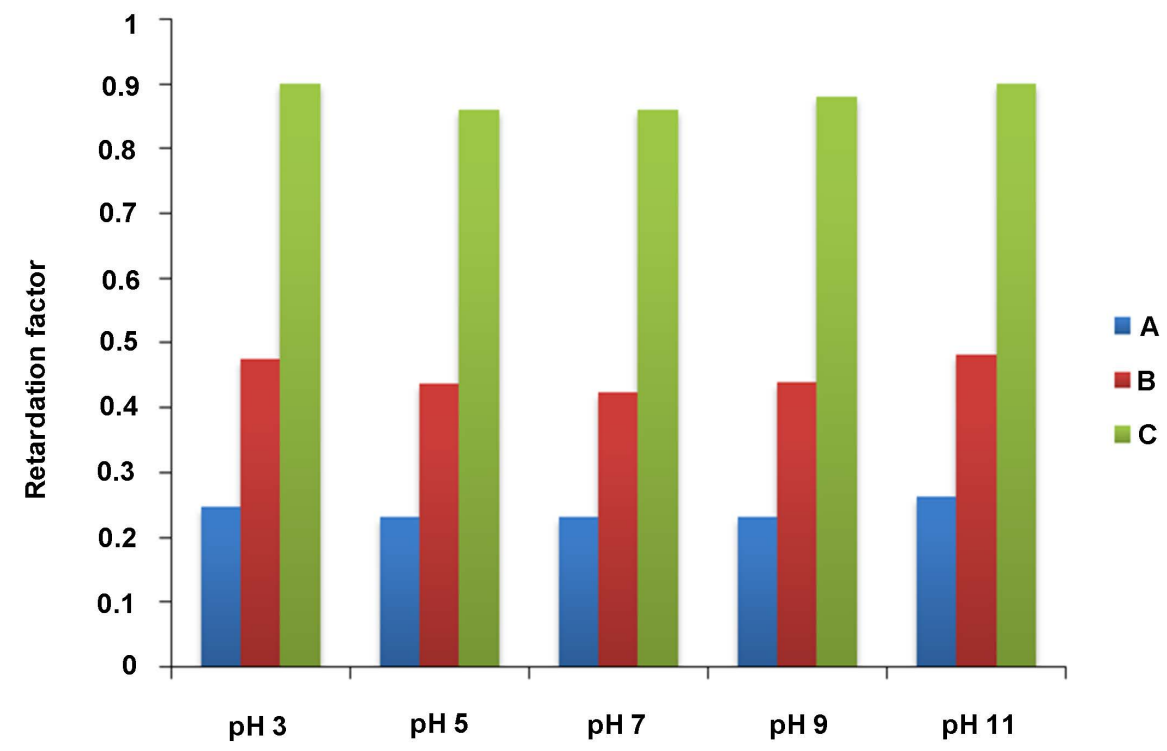

Figure 2. Thin layer chromatogram of oil extracted from maize grains. Three major spots $(\mathrm{A}, \mathrm{B}, \mathrm{C})$ were marked and the retardation factor $(\mathrm{C}>\mathrm{B}>\mathrm{A})$ determined for each spot.

$18.62 \pm 1.2,15.83 \pm 2.2,13.66 \pm 0.9$ to $10.40 \pm 1.1 \mathrm{mg} \mathrm{NaOH} /$ gram Oil respectively; whilst for the same oil samples iodine number increased from $48.6 \pm 0.4$, $49.0 \pm 0.2,48.8 \pm 0.4,50.5 \pm 0.1$ to $52.1 \pm 0.0$ gram $\mathrm{I}_{2} / 100$ gram Oil respectively. The reciprocal patterns of concentration and the degree of unsaturation changes of fatty acids are shown in this study to be dependent on steeping $\mathrm{pH}$. Compared with the acid values the variations in the iodine numbers were very minimal but consistent with increased UV absorption at $\mathrm{pH} 9$ and 11 in Figure 3. These changes suggested the possibility of alteration in lipase levels and activation during the prolonged steeping period. 


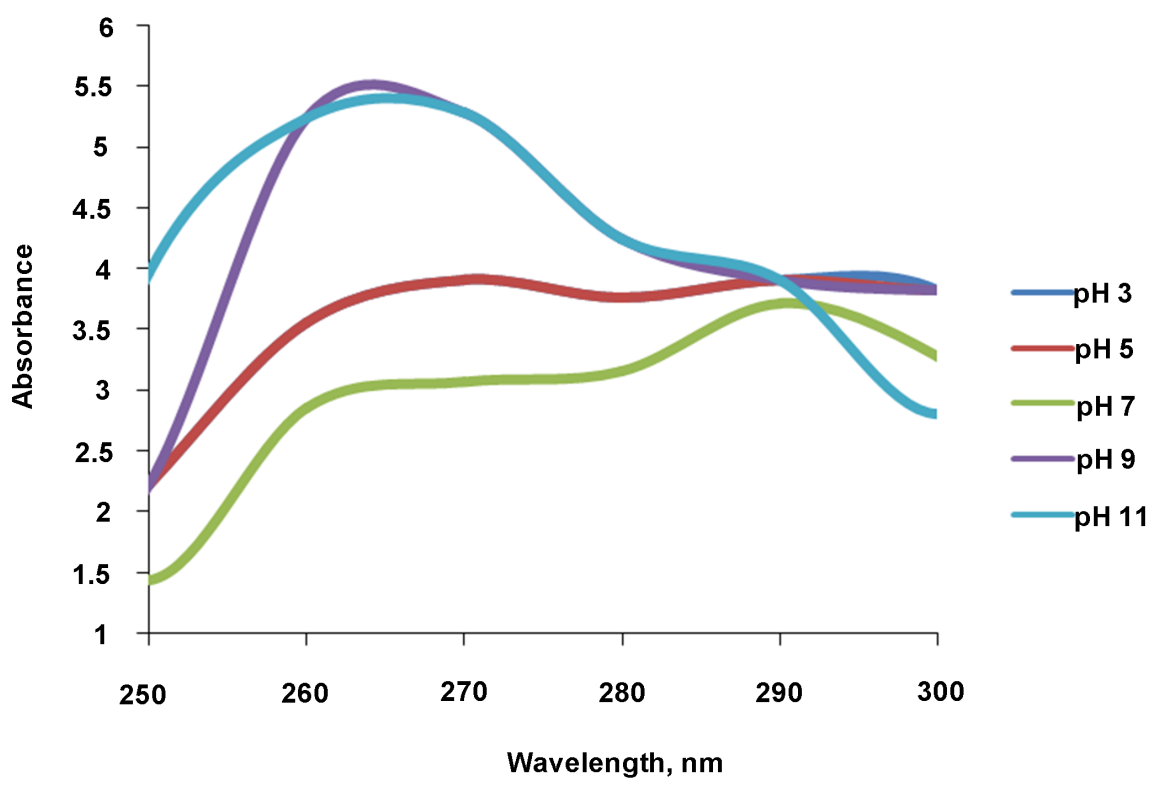

Figure 3. UV-scans of oil extracted from maize grains. Grains steeped in buffer at $\mathrm{pH} 3$, 5,7 gave lower absorptivities than grains steeped at $\mathrm{pH} 9$ and 11. Note: Spectra for $\mathrm{pH} 3$ and $\mathrm{pH} 5$ are superimposed.

\subsection{Protein and Lipase Activity at Different Steeping pH}

Four days of steeping of maize grains at different buffer $\mathrm{pH}$ affected the protein levels as well as lipase activity. There was a consistent drop in protein levels; 37.6 $\pm 3.2,25.8 \pm 2.4,22.4 \pm 3.0,17.5 \pm 1.2,17.1 \pm 2.2 \mathrm{mg} / \mathrm{ml}$ with $\mathrm{pH}$ increases of 3.0, 5.0, 7.0, 9.0 and 11.0 respectively.

Protein content of each of the homogenates was tested for lipase activity. As shown in Table 1, there was a corresponding reduction even though at minimal rate in the lipase levels as the steeping $\mathrm{pH}$ increases.

Lipase activity decreased with increase in steeping $\mathrm{pH}$ (3.0 to 11.0) and the rate of reduction was consistent in all three batches of maize grains used in this study as shown in Table 1 . The capacity of steeping $\mathrm{pH}$ to affect malting and fermentation processes through the alteration of lipase activation, oil yields and components was further validated by its influence on the germination processes of the 'obatanpa' seeds.

\subsection{Effects of Buffered Steeping Media pH on Germination Processes}

In order to conform to our laboratory protocol for germination experiments, maize grains were steeped for a day and not for four days. The number of germinated seeds was counted on each day for five days.

The daily germination data were used to compute average values by five different methods, which are recommended for the measurement of the germination process as shown in Table 2. The average values obtained by the five methods showed a reduction in seed germination when maize grains were steeped in buffers of different $\mathrm{pH}$. This effect was more pronounced at $\mathrm{pH} 3$ and $\mathrm{pH}$ 11.0. 
Table 1. Determination of lipase activity of homogenates of maize grains steeped in buffered media. Experiment was carried out on three $(1,2,3)$ batches of maize grains of each sample.

\begin{tabular}{cccccc}
\hline \multirow{2}{*}{ Steeping pH } & \multicolumn{5}{c}{ Lipase activity in $\mu$ mol per minute } \\
\cline { 2 - 6 } & 1 & 2 & 3 & Mean activity & \pm STD \\
\hline 3 & 0.3714 & 0.3352 & 0.3705 & 0.360 & 0.016 \\
5 & 0.3609 & 0.3152 & 0.3581 & 0.345 & 0.021 \\
7 & 0.3305 & 0.3086 & 0.3447 & 0.330 & 0.015 \\
9 & 0.3095 & 0.3019 & 0.339 & 0.317 & 0.016 \\
11 & 0.3000 & 0.2848 & 0.3181 & 0.301 & 0.014 \\
\hline
\end{tabular}

${ }^{\star}$ Lipase activity for a batch is mean of two determinations.

Table 2. Comparison of different methods used to measure germination process of seeds steeped in buffered and in water (control) media.

\begin{tabular}{cccccc}
\hline & GP, \% & GE, \% & EEV, \% & GVc, \% & GVdp, \% \\
\hline Control & $100 \pm 0.00$ & $18.89 \pm 0.65$ & $25.65 \pm 1.48$ & $256.5 \pm 14.84$ & $18.12 \pm 1.01$ \\
pH 3 & $37 \pm 21.21$ & $6.74 \pm 2.64$ & $9.58 \pm 4.12$ & $41.30 \pm 33.51$ & $6.39 \pm 1.76$ \\
pH 5 & $77 \pm 12.72$ & $14.25 \pm 3.14$ & $18.25 \pm 2.47$ & $133.50 \pm 30.12$ & $10.24 \pm 1.18$ \\
pH 7 & $68 \pm 5.65$ & $12.12 \pm 0.17$ & $15.75 \pm 0.35$ & $107 \pm 6.50$ & $10.47 \pm 0.62$ \\
pH 9 & $55 \pm 1.41$ & $10.35 \pm 0.45$ & $13.50 \pm 2.12$ & $74.10 \pm 9.75$ & $9.56 \pm 0.74$ \\
pH 11 & $27 \pm 1.41$ & $4.16 \pm 0.79$ & $5.25 \pm 0.49$ & $14.81 \pm 1.23$ & $3.92 \pm 0.18$ \\
\hline
\end{tabular}

GP = Germination Percent; GE = Germination Energy; EEV = Emergence Energy Value; GVc = Germina tion Value; GVdp = Germination Value.

Germination started on the second day (Day 2) for all samples. The difference in percentage of germination on Day 2 and Day 5 are $60 \%, 23 \%, 49 \%, 50 \%, 29 \%$ and $18 \%$ representing steeping in distilled water as control and in buffers at $\mathrm{pH}$ 3.0, $\mathrm{pH}$ 5.0, $\mathrm{pH} 7.0, \mathrm{pH} 9.0$ and $\mathrm{pH} 11.0$ respectively. However the characteristic pattern of germination of the 'obatanpa' maize seed did not change for the different steeping $\mathrm{pH}$ as shown in Figure 4.

\section{Discussion}

Steeping of grains in water until the attainment of moisture level, which can support enzymatic activity is a convenient stage in malting whereby the activities of enzymes involved in seed germination can be modulated to achieve a desirable malt or fermented product. In developing countries maize are cultivated solely for human consumption contrary to the situation in industrialized countries where maize is used as industrial raw material and animal feed. Some traditional methods of preparing malted and fermented products including corn dough and liquors go through initial stage of steeping of grains in water; a stage that can last for days depending on the product of interest and importantly on the variety of grains [22]. Activation of lipase can affect the flavor of corn based 


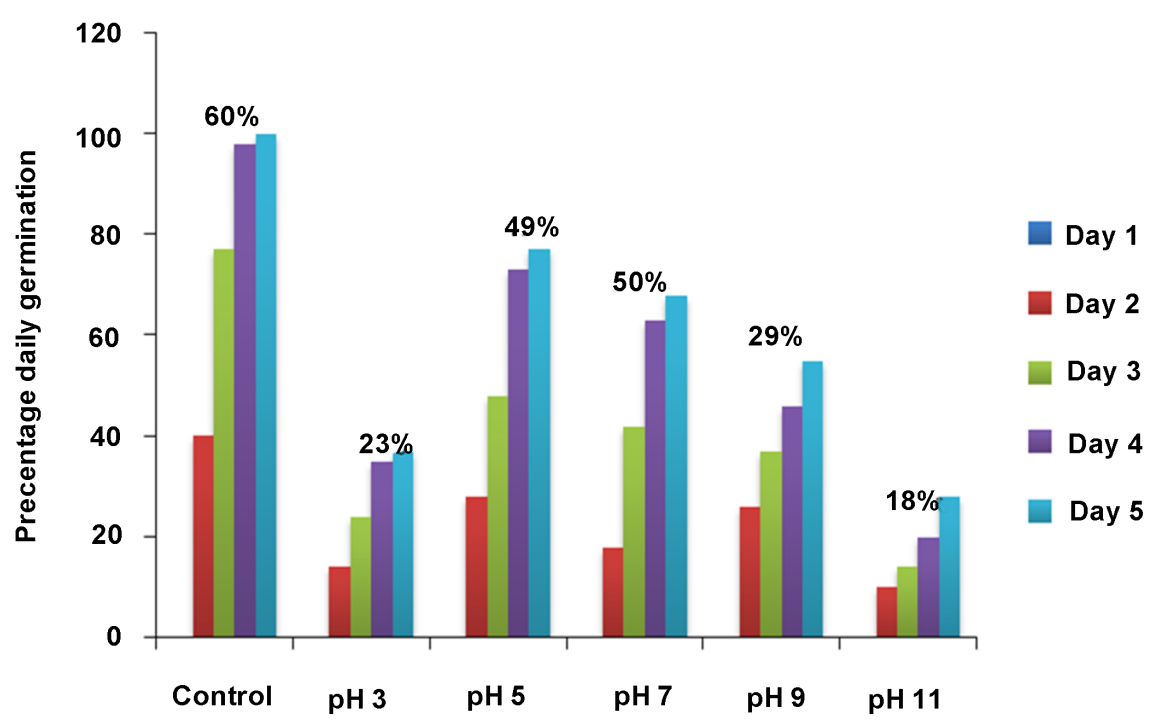

Figure 4. Patterns of germination for treated and untreated maize grains. Number of germinated seeds was recorded for each sample on each day and percentage daily germination calculated. Note: The difference in percentage of seeds germinated on first day of emergence (Day 2) and last day of counting (Day 5) is indicated atop each column cluster. Values for percentage daily germination and difference in percentage of seeds germinated on day of emergence and last day of counting was calculated from the data in Table 2 .

products due to its effects on rancidity and the formation of oxidized unsaturated fatty acids and their protein complexes [6].

\subsection{Ionization of Fatty Acids during Steeping}

This study has shown how pH of the steeping medium can be used to modulate lipase activity as well as the oil yield and components. The universal buffer used as the steeping medium contains buffer components that allowed for the adjustment for different $\mathrm{pH}$. Buffers used as steeping media have same concentration of each of the components but differs in the concentration of hydrogen ions. TLC data suggest unique components of oil extracted from the homogenates of seeds steeped at different $\mathrm{pH}$. Crude corn neutral storage oil is composed of around $90 \%$ triacylglycerol out of which $80 \%$ may compose of triacylglycerols of unsaturated oleic and linoleic fatty acids depending on the maize variety [23]. The TLC data (Figure 2) show that the steeping buffer did not change the key components but the steeping buffer reached the storage tissues changing the protonation, the relative proportions and setting up equilibrium of the $\mathrm{UV}$-absorbing protonated $(\mathrm{FFAH})$ and unprotonated $\left(\mathrm{FFA}^{-}\right)$free fatty acid components by the changes in concentration of hydrogen ions $\left(\mathrm{H}^{+}\right)$:

$\mathrm{FFAH} \leftrightarrows \mathrm{FFA}^{-}+\mathrm{H}^{+}$(steeping buffered media)

These observations are supported by the similarity of the spectra patterns and the equilibrium set between FFAH and FFA, mixtures at constant proportions resulting in the isosbestic point at $290 \mathrm{~nm}$ in Figure 3. 


\subsection{Modulation of Lipase Activity and Oil Yield}

The steeping $\mathrm{pH}$ also affected the oil yield (Figure 1). Oil yield was lower at $\mathrm{pH}$ 9 - 11 compared to $\mathrm{pH} 3$ - 7, which also corroborated with levels of lipase activity at the respective $\mathrm{pH}$ of steeping buffer; very typical of oilseeds [12]. However, the differences in oil levels also support the effect of $\mathrm{pH}$ on the particle size of the ground grains. Higher acidity treatment will produce smaller particle sizes during grinding, which will enhance higher oil extraction [24]. Reducing lipase activity at increasing steeping buffer $\mathrm{pH}$ (Table 2) was corroborated by the decreasing levels of free fatty acid component of the oil. Acid value is often a good measure of the breakdown of the triacylglycerols into free fatty acids, which has an adverse effect on the quality of lipids. The levels of lipase activity and total protein decreased with increasing steeping $\mathrm{pH}$. The reducing free fatty acid levels at increasing buffer $\mathrm{pH}$ did not reflect on the unsaturation levels of the fatty acid. Fatty acid unsaturation as shown by the iodine values was marginally enhanced with increasing steeping $\mathrm{pH}$. This observation might have been due to the high proportion of unsaturation of the oleic and linoleic components of corn oil coupled with the greater sensitivity of the iodine assay for unsaturation of triacylglycerol than of the free fatty acid [23]. It has also been found that plant lipases are specific for the hydrolysis of the ester bonds at $\mathrm{C} 1$ and $\mathrm{C} 3$ positions of the glycerol moiety [25]. Thus, the low lipolytic activity at higher steeping $\mathrm{pH}$ might have resulted in the observed marginal increase in iodine value, which is corroborated by the spectra from Figure 3 . The findings suggest increasing activation of lipase through increasing acidity of the steeping medium, which also affected the proportions of the components (A, B, and C) of the oil.

\subsection{Changes in Germination Capacity and Maintenance of Germination Pattern}

The steeping of the seeds of the 'obatanpa' in buffered steeping media for 24 hours did not change the pattern of seed germination of this maize variety. Seeds steeped in buffered media and in the control media (water) did not germinate on the first day after 24 hours of steeping rather on the second day. However, the germination vigor on the second day was lower for all buffered samples compared to the control. This is also evidenced by the lower percentage of seed germinated between the second day and the fifth day of buffered samples compared to the control sample as shown in Figure 4. Common parameters of monitoring seed germination, shown in Table 2 were reduced when seeds were steeped in buffered media. The germination data implicate the lowering of activities of many gene products and pathways relevant for seed germination for seeds steeped in buffered media compared to seeds steeped in water.

\section{Conclusion}

This study has demonstrated the use of $\mathrm{pH}$ of steeping medium to alter the physiology of the maize oilseeds in terms of lipase activity, oil yield, fatty acid com- 
ponent, fatty acid unsaturation and germination. Physicochemical changes were amenable to simple spectrophotometric monitoring producing series of data that validate lipase and fatty acid ionization changes which ultimately affected oil yield and germination when seeds were steeped in buffered medium.

\section{References}

[1] Jamar, C., Dujardin, P., Fauconnier, M.-L. (2011) Cell Wall Polysaccharides Hydrolysis of Malting Barley (Hordeum vulgare L): A Review. Biotechnology, Agronomy, Society and Environment, 15, 301-13.

[2] Owusu-Mensah, E., Oduro, I., Dziedzoave, N.T. and Sarfo, J.K. (2011) Improving the Malting Qualities of Rice Grain Using Gibberellic Acid (GA3). American Journal of Experimental Agriculture, 1, 432-39. https://doi.org/10.9734/AJEA/2011/361

[3] Owusu-Mensah, E., Oduro, I. and Sarfo, J.K. (2011) Steeping: A Way of Improving the Malting of Rice Grain. Journal of Food Biochemistry, 35, 80-91.

https://doi.org/10.1111/j.1745-4514.2010.00367.x

[4] Ingbian, E.K. and Akpapunam, M.A. (2005) Appraisal of Traditional Technologies in the Processing and Utilization of Mumu; A Cereal Based Local Food Product. African Journal of Food Agriculture, Nutritioin and Development, 5, 1-17.

[5] Mallesh, N.G. and Desikachar, H.S.R. (1985) Studies on Comparative Malting Characteristics of Some Tropical Cereals and Millets. Journal of the Institute of Brewing, 92, 174-176. https://doi.org/10.1002/j.2050-0416.1986.tb04393.x

[6] Lehtinen, P., Killiainen, K., Lehtomaki, I. and Laakso, S. (2002) Effect of Heat Treatment and Lipid Stability in Processed Oats. Journal of Cereal Science, 37, 215-221. https://doi.org/10.1006/jcrs.2002.0496

[7] Damodaran, S. and Arora, A. (2013) Off-Flavor Precursors in Soy Protein Isolate and Novel Strategies for Their Removal. Annual Review of Food Science Technology, 4, 327-346. https://doi.org/10.1146/annurev-food-030212-182650

[8] Glitter, G. (2005) Quantification of Free Fatty Acids and Flavor Characteristics of Kasar Cheeses. Journal of Food Lipids, 12, 209-221. https://doi.org/10.1111/j.1745-4522.2005.00018.x

[9] Sharma, R., Christi, Y. and Banerjee, U.C. (2001) Production, Purification, Characterization and Applications of Lipases. Biotechnology Advances, 19, 627-662.

[10] Palmer, G.H. (1989) Cereals in Malting and Brewing. Journal of Cereal Science and Technology, 17, 312-367.

[11] Dubland, J.A. and Francis, G.A. (2015) Lysosomal Acid Lipase: At Crossroads of Normal and Atherogenic Cholesterol Metabolisms. Frontiers in Cell and Developmental Biology, 3, 1-11. https://doi.org/10.3389/fcell.2015.00003

[12] Huang, A.H.C. and Morcau, R.A. (1978) Lipases in the Storage Tissues of Peanut and Other Oil Seeds during Germination. Planta, 141, 111-116.

https://doi.org/10.1007/BF00387752

[13] Twumasi-Afriyie, S., Badu-Apraku, B., Sallah, P.Y.I., Haag, W., Asiedu, E.A., Marfo, K.A., Ohemeng Dapaah, S. and Dzah, B.D. (1992) The Development and Release of Obatanpa, an Intermediate Maturing Quality Protein Maize Variety in Ghana. Crop Research Institute (Mimeo), $19 \mathrm{p}$.

[14] AOAC (1990) Official Methods of Analysis of the Association of Official Analytical Chemists. 15th Edition, Kenneth Helrich Vol. 2, Oil and Fats, 951.

[15] Gornall, A.G., Baradawill, C.S. and David, M.M. (1949) Determination of Serum Proteins by Means of the Biuret Reaction. Journal of Biological Chemistry, 177, 
751-766.

[16] Maliks, S.V., Kalia, V. and Pundir, C.S. (2000) Immobilization of Porcine Pancrease Lipase on Zirconia Coated Alkylamine Glass using Glutaraldehyde. Indian Journal of Chemical Technology, 7, 64-67.

[17] Ranal, M.A. and de Santana, D.G. (2006) How and Why to Measure the Germination Process. Revista Brasileira de Botanica, 29, 1-11. https://doi.org/10.1590/S0100-84042006000100002

[18] Maguire, J.D. (1962) Speed of Germination-Aid in Selection and Evaluations for Seedling Emergence and Vigor. Crop Science, 2, 176-177. https://doi.org/10.2135/cropsci1962.0011183X000200020033x

[19] Bahuguna, V.K., Pyarelal, K. and Dhawan, V.K. (1987) Standardization of Nursery Techniques (Seed Sowing Methods and Watering Schedules) of Eucalyptus FRI-4 under North Indian Most Tropical Climatic Condition. Indian Forester, 113, 541-549.

[20] Czabator, F.J. (1962) Germination Value: Index Combining Speed and Completeness of Pine Seed Germination. Forest Science, 8, 386-396.

[21] Djavanshir, K. and Pourbeikp, H. (1976) Germination Value-A New Formula. Silvae Genetica, 25, 79-83.

[22] Annan, T., Obodai, M., Anyebuno, G., Tano-Debrah, K. and Amoa-Awua, K. (2015) Characterization of the Dominant Microorganisms Responsible for the Fermentation of Dehulled Maize Grains into Nsiho in Ghana. African Journal of Biotechnology, 14, 1640-1648.

[23] Weber, E.J. (1978) Corn Lipids. Cereal Chemistry, 55, 572-584.

[24] Topollar, H. and Gecgel, U. (2000) Kinetics and Thermodynamics of Oil Extraction from Sunflower Seeds in the Presence of Aqueous Acidic Hexane Solutions. Turkish Journal of Chemistry, 24, 247-253.

[25] Weber, E.J. and Alexander, D.E. (1975) Breeding for Lipid Composition in Corn. Journal of America Oil Chemical Society, 52, 370-373.

https://doi.org/10.1007/BF02639199 